\title{
Exploring relationships between the distribution of giant red shrimp Aristaeomorpha foliacea (Risso, 1827) and environmental factors in the Central-Western Mediterranean Sea
}

\author{
Cinzia Podda, ${ }^{\circledR}$ Francesco Palmas, ${ }^{\S}$ Serenella Cabiddu, Paola Pesci, Andrea Sabatini \\ Department of Life and Environmental Sciences, University of Cagliari, Via Fiorelli 1, 09126 Cagliari, Italy \\ ${ }^{\S}$ Cinzia Podda and Francesco Palmas contributed equally to this work.
}

\begin{abstract}
Mediterranean giant red shrimp Aristaeomorpha foliacea (Risso, 1827) is one of the dominant species in deep-sea megafaunal assemblages, plays a key role in deep-sea communities and it is considered one of the most important targets of deep-water trawl fishing. Although a large number of studies have analysed the spatial distribution of epibenthic crustaceans in bathyal habitats with respect to environmental, geomorphological and hydrological factors, as well as fishing pressure, the manner in which these variables synergistically affect the spatio-temporal changes of giant red shrimp is unclear. To analyse the possible effects of abiotic predictors on the spatio-temporal distribution of giant red shrimp, Generalized Additived Models (GAMs) and Regression Trees were produced. Biological data were collected during the MEDITS trawl surveys carried out in the Sea of Sardinia (2009-2014), during which environmental data were obtained with a multiparametric probe. A longitudinal (west-east) trend was found, with higher abundances at depths of 400-600 m, corresponding to salinity values of 38.1-38.5 psu and temperatures of $13.6-13.8^{\circ} \mathrm{C}$. Our results confirm the existence of a tight linkage between the distribution of the Levantine Intermediate Water (LIW) from the eastern Mediterranean Sea and the preferential habitat characteristics of the giant red shrimp. We suggest that a deeper knowledge of the relationships between abiotic (hydrological) factors in the water column and the distribution of Mediterranean resources, such as the giant red shrimp, can provide valuable support for their better management, at the local scale (Sardinia) and across the whole Mediterranean Sea.
\end{abstract}

\section{INTRODUCTION}

The giant red shrimp Aristaeomorpha foliacea (Risso, 1827) is one of the key species in Mediterranean deep-sea benthic communities and it is also one of the most important target species for Mediterranean bottom trawling (Cau et al., 2002; Guillen et al., 2012; Rinelli et al., 2013, Palmas et al., 2017a). The species is exploited on muddy bottoms, mainly at depths of 400-800 m, using traditional trawl nets (Ragonese et al., 2002; Sbrana et al., 2003; Sabatini et al., 2011; Sala et al., 2015). In 2016, declared landings of red shrimp (A. foliacea jointly with Aristeus antennatus (Risso, 1816)), amounted to $5500 \mathrm{t}$ across the entire Mediterranean Sea (STECF, 2015). Nowadays, deep-water shrimps account for about $5 \%$ of the total professional fishing income in the Mediterranean Sea (STECF, 2019), with increasing catches in Italy and Spain in particular, which are the main producers in Europe (Eumofa, 2019).

In the Mediterranean Sea, giant red shrimp distribution differs among western and eastern basins according to a geographical gradient (Cau et al., 2002; Politou et al., 2004; Cartes et al., 2011a). A. foliacea is predominant in Sardinia, northern and Central Tyrrhenian Sea, Strait of Sicily, Ionian Sea, whereas it is nearly absent in the Ligurian and Catalan Sea, Balearic Islands and eastern Mediterranean basin (Ragonese and Bianchini, 1995; Papaconstantinou and Kapiris, 2003).

Several authors have reported a strong correlation be- tween the geographical distribution of red shrimp and environmental factors, including the geomorphological characteristics of the fishing grounds (e.g. presence of canyons and underwater reliefs) (Abellò et al., 2002, Sabatini et al., 2007, 2011), trophic factors (Cartes et al., 2008), hydrological factors (Ghidalia and Bourgois, 1961; Sardà et al., 2004; Carney, 2005; Company et al., 2008; Guijarro et al., 2008; Massuti et al., 2008; Canals et al., 2009; Cartes et al., 2011a; Cartes et al., 2011b) and fishing pressure (Relini and Orsi Relini, 1987; Bianchini and Ragonese, 1994; Blanchard, 2001; D’Onghia et al., 2005). Despite these studies, many aspects of the interactions among environmental variables and spatial distribution of the species remain unclear, yet.

The aim of this study is to provide further information about the possible relationships between environmental factors and the spatio-temporal distribution of giant red shrimp in Sardinian waters (western Mediterranean), using multivariate models (GAMs and Regression Trees).

\section{METHODS}

\section{Study area}

The seas around Sardinia represent a particularly interesting environment, for their central position in the western Mediterranean basin, its geomorphologic heterogeneity and the presence of extended fishing bottoms (Cau et al., 1994). These features (i.e., submarine canyons 
and seamounts) determine local hydrographic conditions that can facilitate species movement, thus contributing to the peculiar spatial distributions observed in this area (Orrù and Ulzega, 1988; Sabatini et al., 2007).

Data come from the MEDITS survey programme, an international bottom trawl survey, carried out in the Mediterranean since 1994, every year, during the spring and the beginning of summer. This survey has been designed to sample all trawlable areas along coasts from 10 to $800 \mathrm{~m}$ depth. The application of a common standardized protocol allowed to produce biological data on demersal resources (Spedicato et al., 2019).

According to the MEDITS protocol, the seas around Sardinia were subdivided into seven zones: two located in the eastern coast (SE-Area 1, NE-Area 2), one in the northern (N-Area 3), three in the western coast (NW-Area 4, CW-Area 5, SW-Area 6) and one in the southern coast (S-Area 7) (Fig. 1).

\section{Data collection}

Fishing data were collected from the Sea of Sardinia during the summer months from 2009 to 2014; trawl surveys were performed according to Bertrand et al., 2002 using a stratified random sampling design, with the number of experimental hauls proportional to the surface of each depth stratum. A total of 103 experimental hauls were analysed (at depths of 400-700 m), corresponding to the

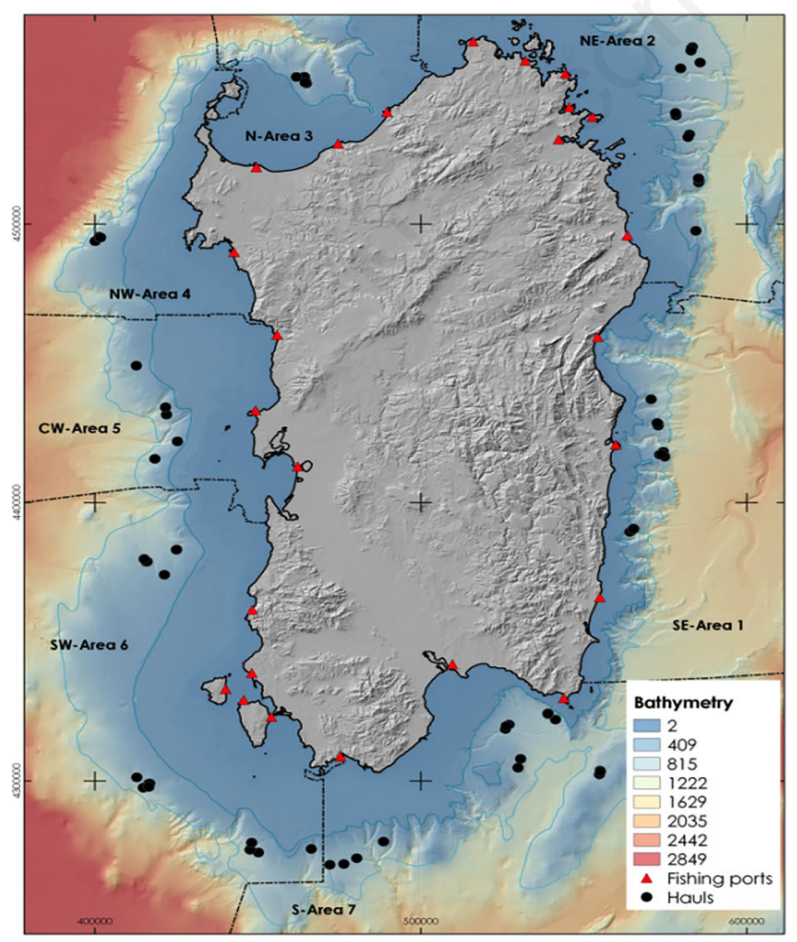

Fig. 1. Map of the study area. sets in which potentially giant shrimp are found. Trawl sensors (SIMRAD) were connected to the net mouth to record the functioning and opening of the wings. Data about horizontal opening net were used to evaluate the swept area (Sparre and Venema, 1998) and to compute standardized density index (di: number of individuals $\mathrm{km}^{-2}$ ).

To investigate the effect of hydrological conditions on species abundance, data of both vertical and longitudinal profiles of temperature $\left({ }^{\circ} \mathrm{C}\right)$, salinity (psu) and depth (m) were recorded using a multi-parameter probe CTD (SBE37 IM Microcat) mounted on the experimental net (in the otter of the trawler, GOC73 net). For each longitudinal profile, we calculated the average temperature (Bot_Temp) and salinity (Bot_Sal) values at the bottom. For each vertical profile, we compiled the temperature (LiwCT) and salinity (LiwCS) at the LIW (Levantine Intermediate Water) core, between 250 and $500 \mathrm{~m}$, the average depth at the bottom (Depth), the longitude and latitude coordinates (lat, lon), the spatio-temporal variables (Year and sampling areas, Areas 1-7) and fishing effort (n.A: number of bottom trawlers that operate in the sampling areas) (Tab. 1). Data on the trawling fleets active in the main ports of Sardinia for the period 2009-2014 were obtained from the European Fleet Register (https://webgate.ec.europa.eu/fleet-europa/search_en).

\section{Statistical analyses}

For the environmental variables, the Zuur et al. (2010) protocol was followed, whereby collinearity was examined by computing pairwise scatter plots to compare continuous covariates; combinations with relevant Spearman's rho coefficients $(\rho>0.7)$ were discarded prior to modelling. Data exploration revealed non-linear patterns among the response variables, as such, giant red shrimp abundance and its relationship with environmental and spatio-temporal variables were described using Generalized Additive Models (GAMs) (Hastie and Tibshirani, 1990; Maunder and Punt, 2004) and Regression Trees (Walsh et al., 2001).

GAMs (Hastie and Tibshirani, 1990; Wood, 2006) are

Tab. 1. Variables and acronyms used for the analysis.

\begin{tabular}{lc} 
Variable & Name of the variables \\
\hline Bottom temperature & Bot_Temp \\
Bottom salinity & Bot_Sal \\
\hline LIW core temperature & LiwCT \\
LIW core salinity & LiwCS \\
\hline Depth & Depth \\
Latitude & lat \\
\hline Longitude & lon \\
Year of sampling & Year \\
\hline Sampling areas & Areas \\
Fishing effort & n.A \\
\hline
\end{tabular}


non-parametric regressions in which part of the linear predictor is specified as a sum of the smoothing functions (smooth function, $s$ ) of the predictor variables; the challenge is to find suitable parametric representations for the smoothing functions and appropriately control the degree of smoothness (Wood and Augustin, 2002). A stepwise backward selection procedure was implemented to identify the best fitting model, based on minimizing the Akaike's Information Criterion (AIC) (Akaike, 1973) values. Model performances were evaluated by obtaining the total explained deviance. Further approaches were based on the representation of Generalized Additive Mixed Models (GAMMs) as an extension of GAMs; GAMMs suggest a more complex structure than ordinary additive model and include smoothing terms as random effects (Wood, 2006). The prediction of the spatial aggregations of species was obtained by means of Gaussian process kriging model implemented in $m g c v$ R package (Wood, 2006).

Regression Trees (Morgan and Sonquist, 1963), based on a recursive partitioning regression, were used to validate the obtained results. These models break data into left and right branches, whereby the splitting rules are defined by the predictor variable values. Splitting continues until the 'terminal' nodes, wherein response values become similar within a node or data are too sparse for additional splitting. At the terminal node, the predicted response is the average or majority of the response values within that node for continuous or discrete variables. The sizes of the regression tree structure were examined because the vertical position of the nodes is an important function that reflects the degree of the relationship between variables (Clark and Pregibon, 1992).

All statistical analyses were performed using R 3.3.1, with a significance level of $\mathrm{P}<0.05$ ( $\mathrm{R}$ Core Team, 2019). The GAM approach, as proposed by Wood (2006), was performed using the library $m g c v$ and the Regression Tree with rpart.

\section{RESULTS}

Density of giant red shrimp, sampled between 399 and $711 \mathrm{~m}$ depth, showed marked inter-annual fluctuations in all investigated areas. Highest average densities were recorded in the southern (S-Area 7), northern (N-Area 3) and north-eastern areas of Sardinia (NE-Area 2), while the lowest density was recorded in north western area (NW-Area 4) (Tab. 2).

The exploratory analysis of environmental data showed a significant correlation $(\rho=0.93)$ between bottom salinity (Bot_Sal) and salinity at LIW strata (LiwCS). As such, Bot_Sal and LIWCS were considered redundant and were then included separately in the predictive models.

The best density model for $A$. foliacea was a GAMM $(\mathrm{AIC}=346.9)$ without random effect, that explains the $25 \%$ of the total deviance. The final model included geographical coordinates (lat, lon), depth (Depth), bottom temperature (Bot_Temp), bottom salinity (Bot_Sal) and fishing effort (n.A) (Tab. 3), according to the equation:

(1) $(\mathrm{di} \sim \mathrm{s}($ lat, lon $)+\mathrm{s}($ Depth $)+$

$\mathrm{s}($ Bot_Temp $)+\mathrm{s}($ Bot_Sal $)+\mathrm{s}($ lat, lon, n.A $))$

The cumulative effect of the covariates are illustrated in Fig. 2, where the giant red shrimps' aggregation areas are reported. Highest abundances were recorded in southeastern and northern areas (Area 3 and 7). Important areas of aggregation were also observed throughout the eastern areas (Areas 1,2), where A. foliacea showed intermediate densities. Depth, bottom temperature (Bot_Temp) and bottom salinity (Bot_Sal) showed a negative correlation. Species density increased at depths between 400 and 600 $\mathrm{m}$ where bottom temperatures reach values between 13.6 ${ }^{\circ} \mathrm{C}$ and $13.8^{\circ} \mathrm{C}$ and bottom salinity between 38.1 and 38.55 psu (Fig. 2).

The Regression Tree showed similar result with a significant relationship with environmental variables as selected in GAMM models. The density was mainly influenced, at its first branch, by longitude values $\geq 4278000$. Later, a secondary branch was observed at depths $\geq 580.2 \mathrm{~m}$ (94 record). This node splits into two branches, which were influenced by latitude values $\geq 460000$ ( 50 records) and latitude values $<600000$ (44 records), respectively, and average depth $<565.6 \mathrm{~m}$ ( 20 records) and bottom salinity $\geq 38.55$ psu, respectively ( 24

Tab. 2. Density index (average value $\pm \mathrm{SE}$ ) of the investigated species in each one of the seven zones selected and each year.

\begin{tabular}{lccccccc} 
& 2009 & 2010 & 2011 & 2012 & 2013 & 2014 \\
Area 1 & $639.4 \pm 27.6$ & $2239.2 \pm 40.3$ & $431.5 \pm 30.9$ & $509 \pm 28.5$ & $404.3 \pm 24.2$ & $71.5 \pm 10$ \\
Area 2 & $1053.75 \pm 41.8$ & $178.2 \pm 18.2$ & $758.3 \pm 34.7$ & $10.5 \pm 4.6$ & $199.7 \pm 15.4$ & $455.8 \pm 22.8$ \\
\hline Area 3 & $1009 \pm 29.1$ & $499 \pm 13.1$ & $364.7 \pm 11.7$ & $1965.7 \pm 45.4$ & $1190 \pm 21.3$ & 0 & $2736 \pm 0$ \\
Area 4 & 0 & $23 \pm 0$ & $1364 \pm 0$ & $1540 \pm 0$ & $106 \pm 0$ & $104.5 \pm 14.4$ \\
\hline Area 5 & $78.5 \pm 4.1$ & $231 \pm 0$ & $12 \pm 4.9$ & 0 & $870 \pm 46.9$ & $103 \pm 0$ \\
Area 6 & $256 \pm 0$ & $148 \pm 0$ & $315 \pm 0$ & $115 \pm 0$ & $24 \pm 1.2$ & $800.6 \pm 44.2$ \\
\hline Area 7 & $2409.3 \pm 67.4$ & $1646.8 \pm 59.6$ & $202 \pm 0$ & $1621.3 \pm 52.9$ & $1013 \pm 38.2$ & \\
\hline
\end{tabular}


records). Our data confirm the significance of the results obtained from the GAMM model: density was affected by the depth, longitude, latitude and bottom salinity (Fig. 3).

\section{DISCUSSION AND CONCLUSIONS}

Changes in environmental conditions can influence the life traits of marine organisms in different ways: by impacting spawning, growth and recruitment (Pankhurst and Munday, 2011; Beggs et al., 2013), prey availability and prey-predator relationships (Fanelli and Cartes, 2010) or by altering their spatial distribution (Perry et al., 2005). These impacts can be exacerbated by the effects of human activities, such as fishing pressure, which may impair the resistance and resilience of marine populations against environmental changes (Anderson et al., 2008).

Due to the importance of $A$. foliacea in the deepwater communities of the Mediterranean Sea, many studies focused on the biology, ecology and fishery (Pal- mas et al., 2017a and references therein). Other authors have analysed the effects of different hydrological conditions (i.e., depth, temperature and salinity) on the species' distribution (Yahiaoui, 1994; Cau et al., 2002; Politou et al., 2004; Sardà et al., 2004; Company et al., 2008; Eumofa, 2019). Spatial distribution has also been related to the cascading of dense shelf waters along the slope (Company et al., 2008), geomorphology (presence

Tab. 3. GAMM summary results for the abundance of giant red shrimps.

\begin{tabular}{lcc} 
Variables & p-value & $\%$ of variation explained \\
$\mathrm{s}($ lat, lon $)$ & $0.000565^{* * *}$ & \\
$\mathrm{~s}($ Detph $)$ & $3.62 \mathrm{e}-06^{* * *}$ & \\
$\mathrm{~s}($ Bot_Temp) & $0.003380^{* *}$ & $25 \%$ \\
$\mathrm{~s}($ Bot_Sal $)$ & $0.019274^{*}$ & \\
$\mathrm{~s}($ lat, lon, $\mathrm{n} / \mathrm{A})$ & $1.86 \mathrm{e}-05^{* * *}$ & \\
\hline
\end{tabular}
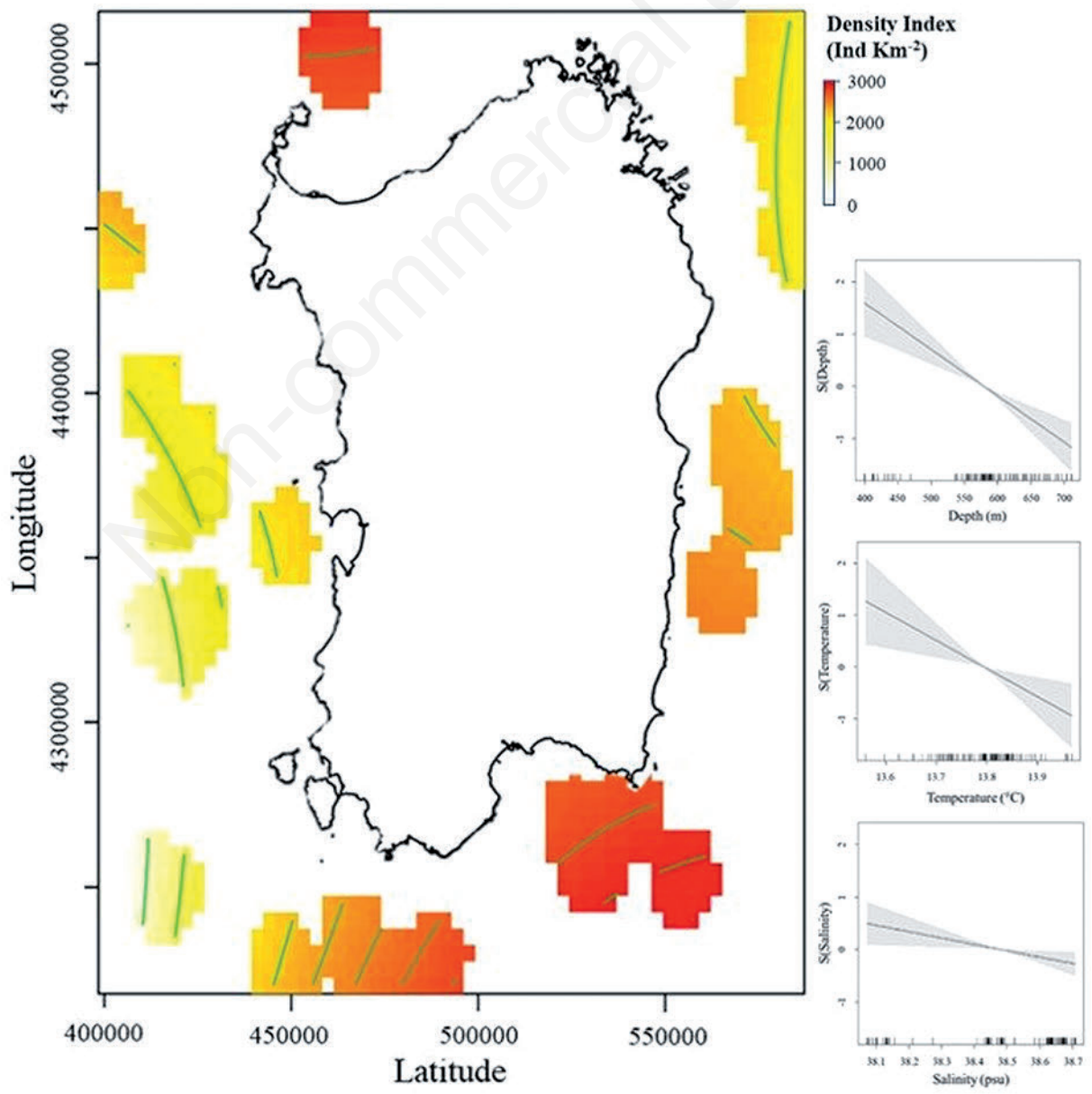

Fig. 2. Generalized additive model (GAM)-derived effect of covariate modelling for the density index of giant red shrimps. Shaded areas and dashed lines indicate $95 \%$ confidence bands. 
of canyons and seamounts) (Sabatini et al., 2007, 2011), bottom type (Cartes et al., 2008), oceanographic features (Guijarro et al., 2008) and fishing activity (D'Onghia et al., 2005; Carlucci et al., 2006). For instance, the abundance of the giant red shrimp would result high patchy as a consequence of several intermingling factors (Rinelli et al., 2013, Masnadi et al., 2018), which could act as drivers in shaping the spatial distribution of the species. The available literature reports a longitudinal gradient of the spatial distribution of A. foliacea, with abundances in the central and easternmost areas higher than those in the westernmost areas of the Mediterranean Sea (Cau et al., 2002; Politou et al., 2004; Cardinale et al., 2017). In the Mediterranean Sea, giant red shrimp hotspots were observed: i) in the Sardinian Sea, where the species was more abundant in the southern grounds (Cau et al., 2002); ii) in the central Tyrrhenian Sea, where the species reach greater numbers in the southern sector; iii) in southern Sicily and in the western sector of the Ionian Sea where this species showed a consistent southern aggregation (Ragonese et al., 1994; D’Onghia et al., 2003).

Giant red shrimps occur at depths of 160-1330 m, and are prevalently caught at depths of 500-800 m (Maiorano et al., 2010; Bayhan et al., 2015; Deval et al., 2016; Eu- mofa, 2019, Guijarro et al., 2019), although populations can be found also at shallower depths, typically between 100 and $160 \mathrm{~m}$ in the the Ionian Sea and in southern Italy canyons (Relini and Relini-Orsi, 1987; Matarrese et al., 1995; D’Onghia et al., 1996, Sabatini et al., 2007). Such a wide vertical distribution is due to the fact that the species is capable of wide daily movements along the water column (Kapiris et al., 2010; Fernández et al., 2013), ascending to shallower depths during the night (Cau and Deiana, 1982), particularly in winter. This phenomenon is more evident in canyons and seamounts, where bottom climbing on the continental slope edge can be observed (Matarrese et al., 1995, Sabatini et al., 2007, 2011; Palmas et al., 2015, 2017b). A. foliacea prefers the warmer and more saline waters of the eastern Mediterranean basin than the western basin. In particular, the species appreciates seawater temperatures close to $13^{\circ} \mathrm{C}$ and salinities of 38.5 psu (Ghidalia and Bourgois, 1961; Yahiaoui, 1994; Cartes et al., 2002; Politou et al., 2004; Sardà et al., 2004; Company et al., 2008; Noël, 2015), corresponding to the typical hydrological features of the Levantine Intermediate Waters (LIW) arriving from the eastern Mediterranean basin. In detail, for the Catalan Sea and the Balearic Islands, red shrimps are abundant between 12.8 and $13.9^{\circ} \mathrm{C}$. Nevertheless, peak densities occur

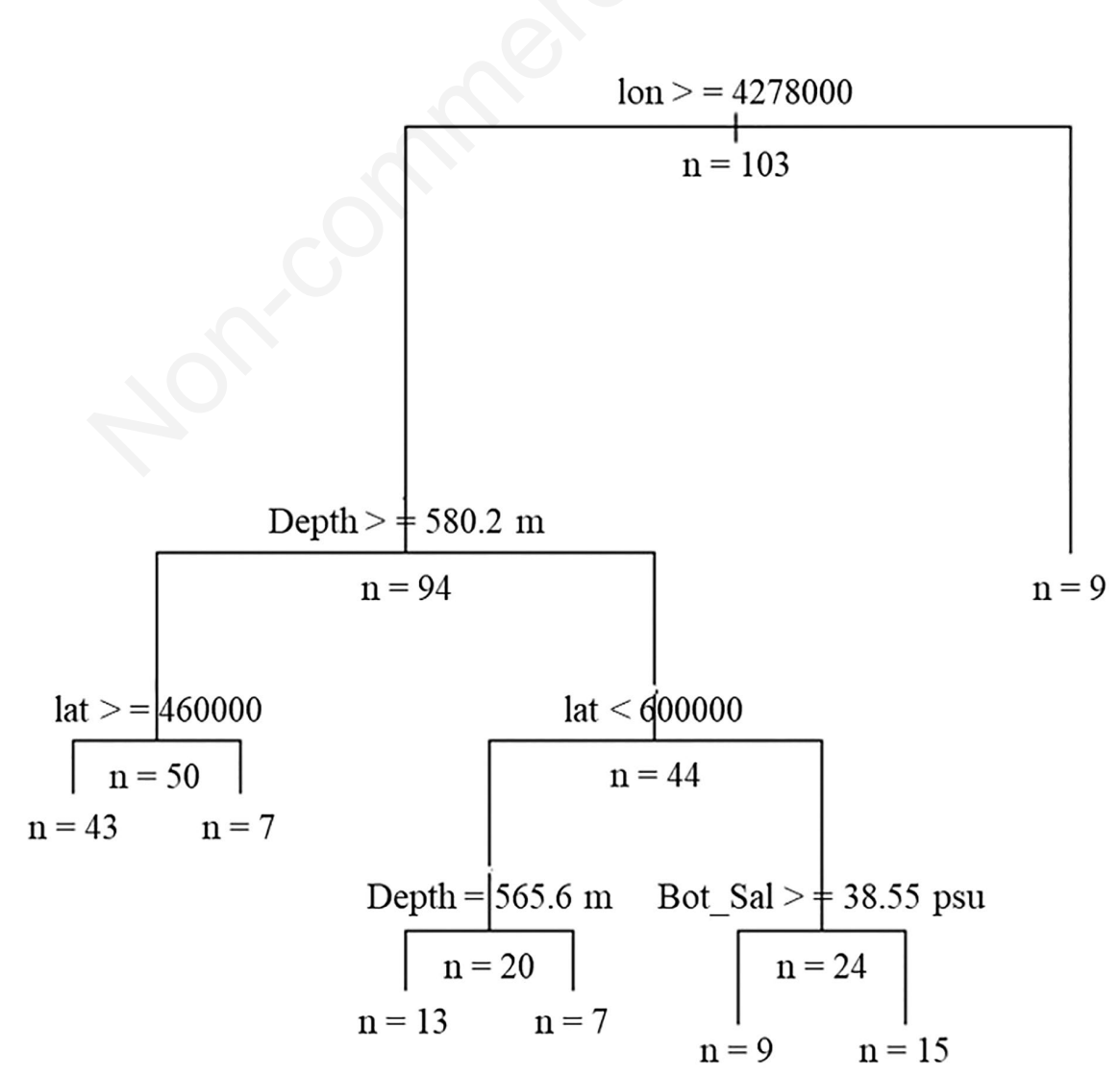

Fig. 3. Regression Tree model on density index of $A$. foliacea. 
at ca. $12.8^{\circ} \mathrm{C}$ at depths between 900 and $1000 \mathrm{~m}$ (Demestre and Martín, 1993, Sardà et al., 1998, Tudela et al., 2003). This species can be found also from 80 to 600 $\mathrm{m}$ depth off Algeria and Tunisia at temperatures ranging from 12.8 to $14^{\circ} \mathrm{C}$ (Yahiaoui, 1994). In the Ionian Sea, red shrimps have been reported at different depths, but the highest abundances were found at $600-800 \mathrm{~m}$ depths (Deval et al., 2016), both in the Western (at 13.3 and $13.7^{\circ} \mathrm{C}$ ) and the Eastern (at up $13.9^{\circ} \mathrm{C}$ ) basin (Politou et al., 2004). The hypothetical distribution range of this species could extend down to $2800 \mathrm{~m}$ depth (Sardà et al., 2004).

The spatio-temporal variability of the species abundance would seem also related to large-scale climatic indices, such as the North Atlantic Oscillation (NAO) (D'Onghia et al., 2012) even if the variability can differ among even nearby ports (Hidalgo et al., 2015). All of the above delineated abiotic constraints are associated with an intense and prolonged fisheries exploitation, resulting in concurring effects which make difficult the interpretation of the whole picture of the species' distribution (Rinelli et al., 2013; Sabatini et al., 2013).

Overall, our study confirms either the general assumption by which the abundance of $A$. foliacea follows a longitudinal eastern-western gradient or the influence of environmental variables in its spatial distribution and abundance in the seas surrounding Sardinia (Murenu et al., 1994; Cau et al., 2002; Rinelli et al., 2013). The highest abundances of giant red shrimp were observed in the southern (S-Area 7) and northern (N-Area 3) areas, confirming a longitudinal trend for the distribution of the species, with an increasing western-eastern pattern (Guijarro et al., 2019). The particular variability in the hydrographic conditions of the Sardinian seas determine the presence of different habitats that provide a complex system of environmental patches, which, in turn, are reflected in the distribution and abundance of the deep-water red shrimps along the Sardinian slopes. Our data confirm also that giant red shrimp, preferring depths of 400-600 m, salinity levels between 38.1 and 38.5 psu and temperatures between $13.6^{\circ} \mathrm{C}$ and $13.8^{\circ} \mathrm{C}$, seem to concentrate in Levantine Intermediate Waters (LIW).

In conclusion, due to response complexity, it is not always easy to establish unique relationships between a single environmental (abiotic or biotic) factor and a biological response. The multitude of pathways through which hydrological features affect marine populations often makes it difficult to establish univocal, significant and non-spurious connections between the climate and ecological responses (Ottersen et al., 2010).

In this work, the use of in situ environmental observations helped to clarify the role of some key environmental process on giant red shrimp abundance that can be extend across the whole Mediterranean distributive scenario.

\section{Corresponding author: cpodda@unica.it}

Key words: Aristaeomorpha foliacea; giant red shrimp; abundance; distribution models; environmental effects; Mediterranean Sea.

Received: 7 November 2020.

Accepted: 15 December 2020.

This work is licensed under a Creative Commons Attribution NonCommercial 4.0 License (CC BY-NC 4.0).

${ }^{\circ}$ Copyright: the Author(s), 2020

Licensee PAGEPress, Italy

Advances in Oceanography and Limnology, 2020; 11:9271

DOI: 10.4081/aiol.2020.9471

\section{REFERENCES}

Abelló P, Carbonell A, Torres P, 2002. Biogeography of epibenthic crustaceans on the shelf and upper slope off the Iberian Peninsula Mediterranean coasts: implications for the establishment of natural management areas. Sci. Mar. 66:183-198.

Akaike H, 1973. Information theory and an extension of the maximum likelihood principle, p. 267-281. In: Second International Symposium on Information Theory. B.N. Petrov, F. Csaki (eds) Budapest Akademiai Kiado.

Anderson CNK, Hsieh C, Sandin SA, Hewitt R, Hollowed A, Beddington J, May RM, Sugihara G., 2008. Why fishing magnifies fluctuations in fish abundance. Nature 452: 835-839.

Bayhan KY, Cartes JE, Fanelli E, 2015. Biological condition and trophic ecology of the deep-water shrimp Aristaeomorpha foliacea in the Levantine Sea (SW Turkey). Mediterr. Mar. Sci. 16:46.

Beggs SE, Cardinale M, Gowen RJ, Bartolino V, 2013. Linking cod (Gadus morhua) and climate: investigating variability in Irish Sea cod recruitment. Fish. Oceanogr. 23:54-64.

Bertrand JA, Gil De Sola L, Papaconstantinou C, Relini G, Souplet A, 2002. The general specifications of the Medits surveys. Sci. Mar. 66:9-17.

Bianchini ML, Ragonese S, 1994. Proceedings of the International Workshop on 'Life Cycles and Fisheries of the Deep Water Red Shrimps Aristaeomorpha foliacea and Aristeus antennatus'. N.T.R. I.T.P.P. Special Publication 3: 87 pp.

Blanchard F, 2001. The effect of fishing on demersal fish community dynamics: an hypothesis. ICES J. Mar. Sci. 58: 711-718.

Canals M, Danovaro R, Heussner S, Lykousis V, Puig P, Trincardi F, Calafat AM, Durrieu de Madron X, Palanques A, SanchezVidal A, 2009. Cascades in Mediterranean submarine grand canyon. Oceanogr. 22:26-43.

Cardinale M, Osio GC, Scarcella G, 2017. Mediterranean Sea: A failure of the European fisheries management system. Front. Mar. Sci. 4:72.

Carlucci R, D’Onghia G, Sion L, Maiorano P, Tursi A, 2006. Selectivity parameters and size at first maturity in deep-water shrimps, Aristaeomorpha foliacea (Risso, 1827) and Aristeus antennatus (Risso, 1816), from the north-western Ionian Sea (Mediterranean Sea). In: Thessalou-Legaki, M. (Ed.), Issues 
of Decapod Crustacean Biology. Hydrobiologia 557:145-154.

Carney RS, 2005. Zonation of deep biota on continental margins. Oceanogr. Mar. Biol. 43:211-278.

Cartes JE, Abelló P, Lloris D, Carbonell A, Torres P, Maynou F, Gil de Sola L, 2002. Feeding guilds of western Mediterranean demersal fish and crustaceans: an analysis based on a spring survey. Sci. Mar. 66:S209-220.

Cartes JE, Papiol V, Guijarro B, 2008. The feeding and diet of the deep-sea shrimp Aristeus antennatus off the Balearic Islands (Western Mediterranean): Influence of environmental factors and relationship with the biological cycle. Progress Oceanogr. 79:37-54.

Cartes JE, Maynou F, Fanelli E, 2011a. Nile damming as plausible cause of extinction and drop in abundance of deep-sea shrimp in the western Mediterranean over broad spatial scales. Progress Oceanogr. 91:286-294.

Cartes JE, Maynou F, Abelló P, Emelianov M, Gil de Sola L, Solé M, 2011b. Long-term changes in the abundance and deepening of the deep-sea shrimp Aristaeomorpha foliacea in the Balearic Basin: Relationships with hydrographic changes at the Levantine Intermediate Water. J. Mar. Syst. 88:516-525.

Cau A, Deiana AM, 1982. [Sulle variazioni di cattura del gambero rosso Aristaeomorpha foliacea in relazione alla sua EcoEtologia].[Article in Italian]. Boll Musei Istit Biol Università Genova 50:145-150.

Cau A, Sabatini A, Murenu M, Follesa MC, Cuccu D, 1994. [Considerazioni sullo stato di sfruttamento delle risorse demersali (Mari di Sardegna) ].[Article in Italian]. Biol. Mar. Mediterr. 1:67-76.

Cau A, Carbonell A, Follesa MC, Mannini A, Norrito G, Orsi-Relini L, Politou CY, Ragonese S, Rinelli P, 2002. MEDITSbased information on the deep-water red shrimps Aristaeomorpha foliacea and Aristeus antennatus (Crustacea: Decapoda: Aristeidae). Sci. Mar. 66:103-124.

Clark LA, Pregibon D, 1992. Tree-based Models p. 377-420. In: Hastie JMCaTJ, editor: Wadsworth.

Company JB, Puig P, Sardà F, Palanques A, Latasa M, Scharek R, 2008. Climate influence on deep sea populations. PLoS One 3:e1431.

D’Onghia G, Mastrototaro F, Matarrese A, Politou CY, 2003. Biodiversity of the upper slope demersal community in the eastern Mediterranean: Preliminary comparison between two areas with and without trawl fishing. J. Northw. Atl. Fish. Sci. 31:263-273.

D’Onghia G, Capezzuto F, Mytilineou C, Maiorano P, Kapiris K, Carlucci R, Sion L, Tursi A, 2005. Comparison of the population structure and dynamics of Aristeus antennatus (Risso, 1816) between exploited and unexploited areas in the Mediterranean Sea. Fish. Res. 76:22-38.

D’Onghia G, Giove A, Maiorano P, Carlucci R, Minerva M, Capezzuto F, Sion L, 2012. Exploring relationshipsbetween demersal resources and environmental factors in the Ionian Sea (Central Mediterranean). J. Mar. Biol. 27946.

Demestre M, Martìn P, 1993. Optimum exploitation of a demersal resouce in the western Mediterranean: the fishery of the deepwater shrimp Aristeus antennatus (Risso, 1816). Sci. Mar. 2:175-182.

Deval MC, Kapiris K, 2016. A review of biological patterns of the blue-red shrimp Aristeus antennatus in the Mediterranean
Sea: a case study of the population of Antalya Bay, eastern Mediterranean Sea. Sci. Mar. 80:339-348.

European Market Observatory for fisheries and aquaculture (EUMOFA), 2019. The EU fish market, 107 pp. Available from: https://www.eumofa.eu/documents/20178/157549 /EN_The+EU+fish+market_2019.pdf

Fanelli E, Cartes JE, 2010. Temporal variations in the feeding habits and trophic levels of three deep-sea demersal fishes from the western Mediterranean Sea, based on stomach contents and stable isotope analyses. Mar. Ecol. Prog. Ser. 402:213-232.

Fernández MV, Heras S, Viñas J, Maltagliati F, Roldán MI, 2013. Multilocus Comparative Phylogeography of Two Aristeid Shrimps of High Commercial Interest (Aristeus antennatus and Aristaeomorpha foliacea) Reveals Different Responses to Past Environmental Changes. PLoS ONE 8(3): e59033.

Ghidalia W, Bourgois F, 1961. [Influence de la témperature et de l'éclairement sur la distribution des crevettes des moyennes et grandes profondeurs]. Stud. Rev. Gen. Fish. Couns. Medit. FAO 16:1-53.

Guijarro B, Massutí E, Moranta J, Díaz P, 2008. Population dynamics of the red shrimp Aristeus antennatus in the Balearic Islands (western Mediterranean): Short spatio-temporal differences and influence of environmental factors. J. Mar. Syst. 71:385-402.

Guijarro B, Bitetto I, D’Onghia G, Follesa MC, Kapiris K, Mannini A, Marković O, Micallef R, Ragonese S, Skarvelis K, Cau A, 2019. Spatial and temporal patterns in the Mediterranean populations of Aristaeomorpha foliacea and Aristeus antennatus (Crustacea: Decapoda: Aristeidae) based on the MEDITS surveys. Sci. Mar. 83:S57-70.

Guillen J, Maynou F, Floros C, Sampsom D, Conides A, Kapiris K, 2012. A bioeconomic evaluation of the potential for establishing a commercial fishery on two newly developed stocks: The Ionian red shrimp fishery. Sci. Mar. 76:597-605.

Hastie T, Tibshirani R, 1990. Generalized additive models. London: Chapman and Hall.

Hidalgo M, Rueda L, Molinero JC, Guijarro B, Massutì E, 2015. Spatial and temporal variation of seasonal synchrony in the deep-sea shrimp Aristeus antennatus in the Western Mediterranean. J. Mar. Syst. 148:131-141.

Kapiris K, Thessalou-Legaki M, Petrakis G, Conides A, 2010. Ontogenetic shifts and temporal changes in the trophic patterns of the deep-sea red shrimp, Aristaeomorpha foliacea (Decapods: Aristeidae), in the Eastern Ionian Sea (Eastern Mediterranean). Mar. Ecol. 31:341-354.

Maiorano P, Sion L, Carlucci R, Capezzuto F, Giove A, Costantino G, Panza M, D’Onghia G, Tursi A, 2010. The demersal faunal assemblage of the north-western Ionian Sea (central Mediterranean): current knowledge and perspectives. Chem. Ecol. 26:219-240.

Masnadi F, Criscoli A, Lanteri L, Mannini A, Osio GC, Sartor P, Sbrana M, Ligas A, 2018. Effects of environmental and anthropogenic drivers on the spatial distribution of deep-sea shrimps in the Ligurian and Tyrrhenian Seas (NW Mediterranean). Hydrobiologia 816:165-178.

Massutì E, Monserrat S, Oliver P, Moranta J, López-Jurado JJ, Marcos M, Hidalgo M, Guijarro B, Carbonell A, Pereda P, 2008. The influence of oceanographic scenarios on the pop- 
ulation dynamics of demersal resources in the western Mediterranean: Hypothesis for hake and red shrimp off Balearic Islands. J. Mar. Syst. 71:421-438.

Matarrese A, D’Onghia G, Deflorio M, Panza M, Costantino G, 1995. [Recenti acquisizioni sulla distribuzione batimetrica di Aristaeomorpha foliacea e Aristeus antennatus (Crustacea, Decapoda) nel Mar Ionio].[Article in Italian]. Biol. Mar. Medit. 2:299-300.

Maunder MN, Punt AE, 2004. Standardizing catch and effort data: a review of recent approaches. Fish. Res. 70:141-159.

Morgan JN, Sonquist JA, 1963. Problems in the analysis of survey data, and a proposal. J. Amer. Statist. Assoc. 58:415-434.

Murenu M, Cuccu D, Follesa C, Sabatini A, Cau A, 1994. The occurrence of Aristaeomorpha foliacea in Sardinian waters, $p$ 49-50 in: Life Cycles and Fisheries of the Deep-water Red Shrimps Aristaeomorpha foliacea and Aristeus antennatus. Proc. of the International workshop held in the Instituto di Tecnologia della Pesca e del Pescato. Bianchini M. L., S. Ragonese (editors), N.T.R. - I.T.P.P.

Noël P, 2015. [La crevette rouge Aristaeomorpha foliacea (Risso, 1827)], p.1-6. [Article in French]. In: Muséum national d'Histoire naturelle (Ed.). Inventaire national du Patrimoine naturel. Available from: https://inpn.mnhn.fr/fichesEspece/EspecesMarines/Aristaeomorpha_foliacea.pdf

Orrù $\mathrm{P}$, Ulzega A, 1988. [Ricerche geomorfologiche sul canyon Gonone (Sardegna Orientale].[Article in Italian]. Bull. Soc. r. sci. Liège 57:415-427.

Ottersen G, Kim S, Huse G, Polovina JJ, Stenseth NC, 2010. Major pathways by which climate may force marine fish populations. J. Marine Syst. 79:343-360.

Palmas F, Addis P, Cabiddu S, Cuccu D, Follesa MC, Mura M, Olita A, Pesci P, Sabatini A, 2015. Distribution of spawning and nursery grounds for deep-water red shrimps in the central western Mediterranean Sea. Mediterr. Mar. Sci. 16:117-127.

Palmas F, Maiorano P, Sabatini A, 2017a. Aristaeomorpha foliacea. In: Sartor P., Mannini A., Carlucci R., Massaro E., Queirolo S., Sabatini A., Scarcella G., Simoni R. (eds.), Synthesis of the knowledge on biology, ecology and fishery of the halieutic resources of the Italian seas. Biol. Mar. Mediterr. 24:S1-11.

Palmas F, Olita A, Addis P, Sorgente R, Sabatini A, 2017b. Modelling giant red shrimp larval dispersal in the Sardinian seas: density and connectivity scenarios. Fish. Oceanogr. 26: 364-378.

Pankhurst NW, PL Munday, 2011. Effects of climate change on fish reproduction and early life history stages. Mar. Freshwater Res. 62:1015-1026.

Papacostantinou C., Kapiris K, 2003. The biology of the giant red shrimp (Aristaeomorpha foliacea) at an unexploited fishing ground in the Greek Ionian Sea. Fish. Res. 62:37-51.

Perry AL, Low PJ, Ellis JR, Reynolds JD, 2005. Climate change and distribution shifts in marine fishes. Science 308: 1912-1915.

Politou CY, Kapiris K, Maiorano P, Capezzuto F, Dokos J, 2004. Deep-sea Mediterranean biology: the case of Aristaeomorpha foliacea (Risso, 1827) (Crustacea: Decapoda: Aristeidae). Sci. Mar. 68:117-127.

R Core Team, 2019. A language and environment for statistical computing (v. 3.6.0). R Foundation for Statistical Computing, Austria.
Ragonese S, Bianchini ML, 1995. Size at sexual maturity in red shrimp females, Aristaeomorpha foliacea, from the Sicilian Channel (Mediterranean Sea). Crustaceana 68:73-82.

Ragonese S, Bianchini ML, Di Stefano L, 2002. Trawl cod-end selectivity for deepwater red shrimp (Aristaeomorpha foliacea, Risso, 1827) in the Strait of Sicily (Mediterranean Sea). Fish. Res. 57:131-144.

Relini G, Orsi Relini L, 1987. The decline of red shrimp stocks in the Gulf of Genova. Inv. Pesq. 51:254-260.

Rinelli P, Bianchini ML, Casciaro L, Giove A, Mannini A, Profeta A, Politou CY, Ragonese S, Sabatini A, 2013. Occurrence and abundance of the deep-water red shrimps Aristeus antennatus (Risso, 1816) and Aristaeomorpha foliacea (Risso, 1827) in the Mediterranenan Sea. Cah. Biol. Mar. 54:335-347.

Sabatini A, Follesa MC, Locci I, Pendugiu AA, Pesci P, Cau A, 2007. Assemblages in a submarine canyon: influence of depth and time. Hydrobiologia 580:265-271.

Sabatini A, Follesa MC, Locci I, Matta G, Palmas F, Pendugiu AA, Pesci P, Cau A, 2011. Demersal assemblages in two trawl fishing lanes located on the Baronie Seamount (Central Western Mediterranean). J. Mar. Biol. Assoc. U.K. 91:65-75.

Sabatini A, Locci I, Deiana AM, Follesa MC, Gastoni A, Pendungiu AA, Pesci P, Cau A, 2013. Temporal trends in biodiversity of the middle-slope assemblages in Sardinian seas (Central-Western Mediterranean). J. Mar. Biol. Assoc. U.K. 93:1739-1752.

Sala A, Lucchetti A, Perdichizzi A, Herrmann B, Rinelli P, 2015. Is square-mesh better selective than larger mesh? A perspective on the management for Mediterranean trawl fisheries. Fish. Res. 161:182-190.

Sardà F, Maynou F, Tallò L, 1998. Seasonal and spatial mobility patterns of rose shrimp (Aristeus antennatus, Risso 1816) in the western Mediterranean: results of a long-term study. Mar. Ecol. Prog. Ser. 159:133-141.

Sardà F, Calafat A, Mar Flexas M, Tselepides A, Canals M, Espino M, Tursi A, 2004. An introduction to Mediterranean deep-sea biology. Sci. Mar. 68:7-38.

Sbrana M, Sartor P, Belcari P, 2003. Analysis of the factors affecting crustacean trawl fishery catch rates in the northern Tyrrhenian Sea (western Mediterranean). Fish. Res. 65: 271-284.

Sparre P, Venema SC, 1998. Introduction to tropical fish stock assessment. Part 1. FAO Fisheries Technical Paper 306/1. FAO, Rome: 337 pp.

Spedicato MT, Massutí E, Mérigot B, Tserpes G, Jadaud A, Relini $\mathrm{G}, 2019$. The MEDITS trawl survey specifications in an ecosystem approach to fishery management. Sci. Mar. 83:9-20.

STECF, 2015. Mediterranean assessments part 1 (STECF-15- 18). EUR 27638 EN, JRC 98676. Publications Office of the European Union, Luxembourg.

STECF, 2019. In: Carvalho, N., Keatinge, M., Guillen Garcia, J. (Eds.), Annual Economic Report on the EU Fishing Fleet (STECF 19-06).

Tudela S, Sardà F, Maynou F, Demestre M, 2003. Influence of submarine distribution of the deep-warer shrimp, Aristeus antennatus (Risso, 1816) in the NW Mediterranean. Crustaceana 76(2):217-225.

Walsh WA, Kleiber P, 2001. Generalized additive model and regression tree analyses of blue shark (Prionace glauca) catch rates by the Hawaii-based commercial longline fishery. Fish. 
Res. 53:115-131.

Wood SN, Augustin NH, 2002. GAMs with integrated model selection using penalized regression splines and applications to environmental modelling. Ecol. Model. 157:157-177.

Wood SN, 2006. Generalized additive models: An Introduction with R. CRC.

Yahiaoui M, 1994. Distribution and reproduction cycle of Aristeus antennatus and Aristeomorpha foliacea in Algeria. In: Bian- chini M.L., Ragonese S. (eds.), Life cycles and fisheries of the deep-water red shrimps Aristeomorpha foliacea and Aristeus antennatus. Proceedings of the International Workshop, Istituto di Tecnologia della Pesca e del Pescato (ITPP-CNR), Mazara del Vallo, 3:51-52.

Zuur AF, Ieno EN, Elphick CS, 2010. A protocol for data exploration to avoid common statistical problems. Methods Ecol. Evol. 1:3-14. 